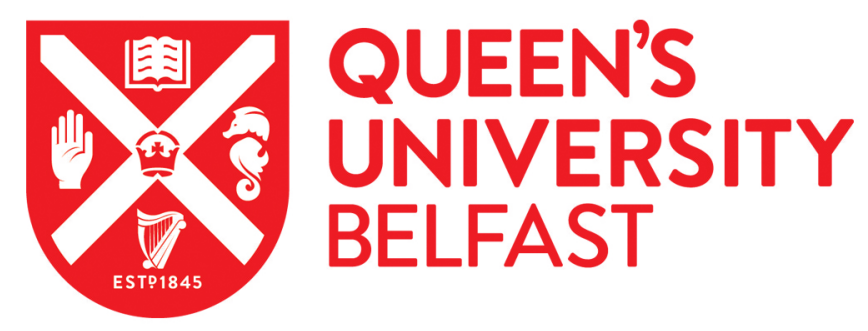

\title{
Holocene lake sediments from the Faiyum Oasis in Egypt: a record of environmental and climate change
}

Marks, L., Salem, A., Welc, F., Nitychoruk, J., Chen, Z., Blaauw, M., Zalat, A., Majecka, A., Szymanek, M., Chodyka, M., Toloczko-Pasek, A., Sun, Q., Zhao, X., \& Jiang, J. (2018). Holocene lake sediments from the Faiyum Oasis in Egypt: a record of environmental and climate change. Boreas, 47, 62-79. https://doi.org/10.1111/bor.12251

\section{Published in:}

Boreas

\section{Document Version:}

Peer reviewed version

Queen's University Belfast - Research Portal:

Link to publication record in Queen's University Belfast Research Portal

\section{Publisher rights}

(c) 2017 Collegium Boreas. Published by John Wiley \& Sons Ltd.

This work is made available online in accordance with the publisher's policies. Please refer to any applicable terms of use of the publisher.

\section{General rights}

Copyright for the publications made accessible via the Queen's University Belfast Research Portal is retained by the author(s) and / or other copyright owners and it is a condition of accessing these publications that users recognise and abide by the legal requirements associated with these rights.

Take down policy

The Research Portal is Queen's institutional repository that provides access to Queen's research output. Every effort has been made to ensure that content in the Research Portal does not infringe any person's rights, or applicable UK laws. If you discover content in the Research Portal that you believe breaches copyright or violates any law, please contact openaccess@qub.ac.uk. 


\title{
Holocene lake sediments from the Faiyum Oasis in Egypt: a record of environmental
} and climate change

\author{
LESZEK MARKS, ALAA SALEM, FABIAN WELC, JERZY NITYCHORUK,
} ZHONGYUAN CHEN, MAARTEN BLAAUW, ABDELFATTAH ZALAT, ALEKSANDRA MAJECKA, MARCIN SZYMANEK, MARTA CHODYKA, ANNA TOŁOCZKO-PASEK, QIANLI SUN, XIAOSHUANG ZHAO AND JUN JIANG

Marks, L., Salem, A., Welc, F., Nitychoruk, J., Chen, Z., Blaauw, M., Zalat, A., Majecka, A., Szymanek, M., Chodyka, M., Tołoczko-Pasek, A., Sun, Q., Zhao, X. \& Jiang, J.: Holocene lake sediments from the Faiyum Oasis in Egypt: a record of environmental and climate change.

The Qarun Lake in the Faiyum Oasis (Egypt) provides a unique record of Holocene environmental and climate change in an arid area largely void of fossil proxy records. Multiple lithological, palaeontological. and geochemical proxies and 32 radiocarbon dates from the 26-m long core FA-1 provide a time-series of the lake transformation. Our results confirm that a permanent lake in the Holocene appeared at $\sim 10$ cal. ka BP. The finelylaminated lake sediments consist of diatomite, in which diatoms and ostracods together with lower concentrations of ions indicate a freshwater environment at the end of the early and middle Holocene. This was closely associated with regular inflows of the Nile water during flood seasons, when the Intertropical Convergence Zone (ITCZ) migrated northwards in Africa, although it has probably never reached the Faiyum Oasis. Local rainfalls, possibly connected with a northern atmospheric circulation, could have been important during winter. Several phases in the lake evolution are recognized, represented by oscillations between deep 
open freshwater conditions during more humid climate and shallow fresh to brackish water during drier episodes. After a long freshwater phase, the lake setting has become more brackish since $\sim 6.2$ cal. ka BP as indicated by diatoms and increasing contents of evaporite ions in the sediment. This clearly shows that since that time the lake has become occasionally partly desiccated. It resulted from a reduced discharge of the Nile. In the late Holocene the lake was mostly brackish turning gradually into a saline lake. This natural process was interrupted about 2.3 cal. ka BP when a man-made canal facilitated water inflow from the Nile. The examined FA-1 core can be used as the reference age model of climate change in the Holocene and its impact on development and decline of ancient civilisations in northeastern Africa.

Leszek Marks (leszek.marks@uw.edu.pl), Aleksandra Majecka, Marcin Szymanek and Anna Tołoczko-Pasek, University of Warsaw, Faculty of Geology, Warsaw, Poland; Alaa Salem, Kafrelsheikh University, Faculty of Science, Kafrelsheikh, Egypt; Fabian Welc, Cardinal Stefan Wyszyński University, Institute of Archaeology, Warsaw, Poland; Jerzy Nitychoruk and Marta Chodyka, John Paul 2nd State Higher School, Faculty of Economic and Technical. Sciences, Biała Podlaska, Poland; Zhongyuan Chen, Qianli Sun, Xiaoshuang Zhao and Jun Jiang, East China Normal University, State Key Laboratory of Estuarine and Coastal Research, Shanghai, China; Maarten Blaauw, Queen's University Belfast, School of Natural and Built Environment, UK; Abdelfattah Zalat, Tanta University, Faculty of Science, Tanta, Egypt; received accepted............ 
Palaeoclimatic and geoarchaeological data confirm that transformations of natural environment in north-eastern Africa during the Holocene were caused by climate fluctuations. They stimulated the development and collapse of past human cultures and civilisations in the Nile drainage basin (e.g. Kuper \& Kröpelin 2006; Schild \& Wendorf 2013; Welc \& Marks 2014). Long-term south-north migration of the Intertropical Convergence Zone (ITCZ) during early and middle Holocene seems to have been responsible for a major climate change in the northern Nile drainage basin (e.g. Overpeck et al. 1996; Abell \& Hoelzmann 2000; Arz et al. 2003; Hoelzmann et al. 2004; Nicoll 2004; Kröpelin et al. 2008; Welc \& Marks 2014).

The study area of the Faiyum Oasis is presently located in a desert zone, but this region experienced varying degrees of aridity during the Holocene (cf. Kuper \& Kröpelin 2006; Schild \& Wendorf 2013). Lake deposits in the Faiyum Oasis are a unique archive of late Quaternary palaeoclimate data for the northern part of the Nile basin (Flower et al. 2012; Marks et al. 2016). Regular water inflows from the Nile into the Faiyum Oasis in the Holocene resulted from the Indian summer monsoon system in northern Africa that activated seasonal floods in the northern Nile (Weldeab et al. 2007; Woodward et al. 2007; Revel et al. 2014). In the centre of the Faiyum Oasis, a vast freshwater reservoir has formed due to seasonal hydrological connection with the Nile (cf. Fig. 1). The relic of this ancient lake survived until the present as the saline and shallow Qarun Lake (Wendorf \& Schild 1976; Flower et al. 2012, 2013; Zalat 2015; Marks et al. 2016).

The dynamics of hydrological and climatic changes in the Nile drainage basin are reflected in the lithological. and geochemical. characteristics of sediments in the Faiyum Oasis where the lake filled a central part of the depression. Because the Faiyum Oasis was located outside the northern extent of the monsoon rainfalls in the Holocene (cf. Williams et al. 2000; McCorriston 2006), the lake sediments must have reflected mostly local 
hydroclimatic conditions. The lake level fluctuations were highly dependent on the frequency of inflows of the Nile water and the Nile discharge was controlled by the intensity of the remote precipitation regime in the Ethiopian Highlands where two main tributaries of the Nile originate i.e. the Blue Nile and the Atbara rivers (Baioumy et al. 2010; Hassan et al. 2011). During the Holocene the northernmost part of Egypt and the Red Sea have also been influenced by the North Atlantic Circulation, defined also as the Mediterranean Circulation that created winter rainfalls of varying intensity (e.g. Arz et al. 2003; Marks et al. 2016).

The present contribution is focused on environmental and climate changes recorded in lake sediments of the Faiyum Oasis. It partly follows a postulate of Flower et al. (2012) to demonstrate a full potential of the palaeoenvironmental records with a use of a continuous high-resolution analysis of the Holocene sediments in the Faiyum Oasis. Two cores: FA-1 (26 m long) and FA-2 (4 m long) were drilled at the south-eastern shore of the Qarun Lake (Fig. 1) in February 2014. They provided complete and undisturbed succession of the Holocene lake sediments (Marks et al. 2016). Collected samples were subjected to comprehensive laboratory analyses, the most significant results of these are presented in this paper.

\section{Site location and previous studies}

The area of the Faiyum Oasis is estimated at some 1270 to $1700 \mathrm{~km}^{2}$ (Fig. 1). It is located within Eocene and Oligocene rock formations, composed mostly of organodetritic limestones, marls and sandstones of shallow water facies. Oligocene, Late Miocene and Pliocene sedimentary series are overlain by Quaternary sediments, mainly of lacustrine and aeolian origin (Beadnell 1905; Said 1981).

The Faiyum Oasis is one of the most important depressions in the Western Desert of Egypt and the question of its origin has been a subject of numerous disputes and 
controversies. Its current shape had been controlled by subsidence until the Late Eocene (Dolson et al. 2002). A lake could occupy the oasis already in the Pliocene, then it probably dried up in the Pleistocene and intensive deflation occurred, followed by filling with the Nile waters at the beginning of the Holocene (cf. Beadnell 1905; Caton-Thompson \& Gardner 1929). On the other hand, Ball (1939) and Said (1979) suggested that the depression was formed by complex tectonic movements and deflation, active since the Pleistocene to the present time (Kusky et al. 2011).

At present, the northern part of the Faiyum Oasis is occupied by the Qarun Lake (location: $29^{\circ} 26^{\prime} 36^{\prime \prime}-29^{\circ} 31^{\prime} 15^{\prime \prime} \mathrm{N}$ and $30^{\circ} 23^{\prime} 52^{\prime \prime}-30^{\circ} 49^{\prime} 55^{\prime \prime} \mathrm{E}$ ), which is a relic of the early and middle Holocene freshwater reservoir (cf. Caton-Thompson \& Gardner 1934; Wendorf \& Schild 1976). The maximum depth of the Qarun Lake is about $8.5 \mathrm{~m}$ and its water level is equal to $44 \mathrm{~m}$ b.s.l. The reservoir is highly saline $\left(>30 \mathrm{gL}^{-1}\right)$, turbid and devoid of surface outflow, with mean water temperature changing seasonally from 15 to $33^{\circ} \mathrm{C}(\mathrm{El}$ Wakeel 1963; El-Sayed \& Guindy 1999; Flower et al. 2006, 2013; El-Shabrawy \& Dumont 2009).

The Qarun Lake has been studied intensively since the beginning of the 20th century, particularly along its coastline. Previous investigations focused mainly on terrestrial exposures of diatomite in the north-eastern part of the Faiyum Oasis (Aleem 1958; Przybyłowska-Lange 1976; Schild \& Wendorf 1976; Zalat 1991, 1995). This was due to presence of numerous archaeological. sites, mainly of Epipalaeolithic and Neolithic age (Caton-Thompson \& Gardiner 1929; Wendorf \& Schild 1976). These studies resulted in the reconstruction of the main transgressive and regressive phases of the lake, named in turn Paleomoeris, Premoeris, Protomoeris and Moeris (Wendorf \& Schild 1976).

Recent interdisciplinary research during which several drillings were performed in the lake and along the southern shore of the Qarun Lake provided important data concerning the 
122 origin and biostratigraphy of the Holocene lake (Keatings et al. 2010; Flower et al. 2012, 123 2013). The most important was the $21.4 \mathrm{~m}$ long core QARU 9 (Flower et al. 2013). However, 124 its location at the south-western lake shore, as with the other cores (Fig. 1), provided a 125 limited record of hydrodynamic and palaeogeographic transformations of the lake during the 126 Holocene (Marks et al. 2016). Moreover, its chronology was based on only three radiocarbon 127 dates. Therefore, here we present the new borehole FA-1 (Fig. 2), as likely the longest, bestdated and most complete succession of the Holocene lake sediments in north-eastern Africa (e.g. Pachur et al. 1990; Schild \& Wendorf 2001; Kröpelin et al. 2008; Marshall et al. 2009; Baioumy et al. 2010; Flower et al. 2012).

Methodology

Drilling, sampling and lithological analysis

Drilling was performed with a self-propelled American set Acer with hydraulic rig. The core sections were collected in plastic pipes, each $1 \mathrm{~m}$ long and $10 \mathrm{~cm}$ in diameter. The most of the subsequent analysis was done at intervals of $5 \mathrm{~cm}$, except where stated otherwise.

Preliminary lithological description was based on macroscopic inspection of the core, supplemented with detailed examination of selected fragments using an optical microscope. This general lithological-geochemical analysis of sediments enabled the selection of samples for more detailed analyses.

SEM EDS analyses

143 Samples were dried at room temperature and then analyzed using an electron scanning microscope (HITACHI TM 3000), supplied with an energy dispersion spectrometer (SWIFT point analyses were done with using an accelerating voltage of $15 \mathrm{kV}$. The analyses were 
147 performed at the Research Centre on Innovations, John Paul 2nd State Higher School in Biała 148 Podlaska, Poland.

Ion-geochemistry analysis

151 10-mg dried samples were put into $20 \mathrm{ml}$ centrifuge tube vials containing $10 \mathrm{~mL}$ distilled152 deionised water (resistivity of $18 \mathrm{M} \Omega$ ), placed in ultrasonic water bath for 60 min and then shaken by mechanical shaker for $1 \mathrm{~h}$ for complete extraction of ionic compounds. The extracts were filtered with $0.45 \mu \mathrm{m}$ pore size microporous membranes and filtrates were stored at $4{ }^{\circ} \mathrm{C}$ in a clean tube before further analysis. Three anions $\left(\mathrm{SO}_{4}{ }^{2-}, \mathrm{NO}_{3}{ }^{-}\right.$and $\left.\mathrm{Cl}^{-}\right)$and five cations $\left(\mathrm{Na}^{+}, \mathrm{NH}_{4}^{+}, \mathrm{K}^{+}, \mathrm{Mg}^{2+}\right.$ and $\left.\mathrm{Ca}^{2+}\right)$ were determined in aqueous extracts of the filters, prepared in three steps using ultrapure (18 M $\Omega$ ) water. Ion chromatography (IC, Dionex 500, Dionex Corporation, Sunnyvale, California, United States) was used for the analysis at the Institute of Earth Environment, Chinese Academy of Sciences (IEECAS). Blank values were subtracted from sample concentrations. One sample in each group of 10 samples was analyzed twice for quality control. Typical precision (percent relative standard deviation) for six pairs of samples was calculated using the equation: $\mathrm{X}_{\mathrm{i}}=\left(\mathrm{C}_{\mathrm{i} 1}-\mathrm{C}_{\mathrm{i} 2}\right) / \mathrm{C}_{\mathrm{i}}$, where $\mathrm{C}_{\mathrm{i} 1}$ and $\mathrm{C}_{\mathrm{i} 2}$ were routine and duplicate concentrations, $C_{i a}$ was the mean concentration for the measurement pair $\mathrm{i}$ and $\mathrm{Xi}$ was the relative difference. The maximum relative precisions were $1.8 \%$ for $\mathrm{Na}^{+}, 0.9 \%$ for $\mathrm{NH}_{4}{ }^{+}, 0.6 \%$ for $\mathrm{K}^{+}, 4.0 \%$ for $\mathrm{Ca}^{2+}, 1.0 \%$ for $\mathrm{Mg}^{2+}, 1.2 \%$ for $\mathrm{SO}_{4}{ }^{2-}$, $2.6 \%$ for $\mathrm{NO}_{3}{ }^{-}$and $0.3 \%$ for $\mathrm{Cl}^{-}$(Shen et al. 2008).

Diatom analysis

Diatoms were extracted from the studied samples according to the procedure proposed by Zalat (2002) and Zalat \& Servant-Vildary (2005, 2007). Diatom identification and statistical studies were done in the Geological. Department of the Tanta University in Egypt with a use 
172 of Carl Zeiss light microscope combined with digital camera at normal x100 oil immersion

173 objective. In slides sufficiently rich in diatoms, 1000 diatom valves were counted, whereas at 174 least 200 valves were counted in samples with low-diatom concentrations. Percentage 175 contents of species were calculated for estimation of ecological parameters as life-form 176 groups, $\mathrm{pH}$ and salinity. Relative frequencies of every species were calculated as the 177 percentage of total diatom valves (\% TDV) in each sample, and identification of ecological. 178 preferences of diatom species was based on previous works (e.g. Hustedt 1930-1966, 1957; 179 Ehrlich 1973; Stoermer et al. 1975; Gasse 1986; Kilham et al. 1986; Zalat 1991; Wolfe et al. 2000; Bradbury et al. 2004; Zalat \& Servant-Vidary 2007).

\section{Mollusc and ostracod analysis}

Standard methods established by Ložek (1986) were applied for mollusc analysis of 6 sediment samples with abundant shells: five were collected at $5 \mathrm{~cm}$ intervals at depth of 18.9 - $18.7 \mathrm{~m}$ (volume $50 \mathrm{~cm}^{3}$ each) and a single bulk sample at depth $4.0-3.5 \mathrm{~m}\left(370 \mathrm{~cm}^{3}\right)$. Samples were wet-sieved with $0.5 \mathrm{~mm}$ mesh. All shells and their identifiable apical fragments were picked from the dried residue, identified under a binocular microscope (magnification up to 64x) with reference to taxonomical keys (Brown 1994; Götting 2008; Welter-Schultes 2012) and counted (Ložek 1986). Ecological preferences of mollusc species were based on Taraschewski \& Paperna (1981), Brown (1994), Götting (2008), Ghamizi et al. (2010, 2012) and Welter-Schultes (2012).

Ostracod valves and carapaces were studied in 29 samples according to the method described by Löffler (1986). The core was sampled at every $5 \mathrm{~cm}$ at $18.9-18.7$ and $18.1-$ $17.9 \mathrm{~m}$ depth. Samples were collected every $1 \mathrm{~m}$ at $18.1-13.0 \mathrm{~m}$ and $8.0-5.0 \mathrm{~m}$ depth and every $0.5 \mathrm{~m}$ at $13.0-8.0 \mathrm{~m}$ depth. Density of sampling depended on the abundance of fossils. Ten $\mathrm{cm}^{3}$ of sediment per sample were washed through $0.1 \mathrm{~mm}$ mesh sieve. Ostracods were 
taxonomically determined according to Sywula (1974) and Keatings et al. (2010) using a binocular microscope (magnification up to $64 \mathrm{x}$ ).

\section{Radiocarbon dating}

From layers with organic-rich mud or mud with dispersed organic matter, samples were selected for radiocarbon dating. The organic matter could have been produced within the lake itself but also partly derived from external terrestrial sources (for example through inwash from local heavy rainfall or periodical floods of the Nile). AMS dating was done at the Poznań Radiocarbon Laboratory in Poland using graphite targets (Goslar et al. 2004). Conventional ${ }^{14} \mathrm{C}$ ages were calculated using corrections for isotopic fractionation according to Stuiver \& Polach (1977). The $\delta^{13} \mathrm{C}$ values cannot be used for palaeoecological reconstructions, because they were measured in the graphite prepared from the samples, and the graphitisation process introduces significant isotopic fractionation. The second point is that the AMS spectrometer introduces fractionation, too. The $\delta^{13} \mathrm{C}$ values reflect therefore the original isotopic composition in the sample very roughly only. Nevertheless, this $\delta^{13} \mathrm{C}$ measurement is fully suitable for fractionation correction of ${ }^{14} \mathrm{C} /{ }^{12} \mathrm{C}$ ratios.

Calibration of ${ }^{14} \mathrm{C}$ age was performed (Fig. 3), using OxCal ver. 4.2 software (http://c14.arch.ox.ac.uk) and the northern hemisphere terrestrial calibration curve IntCal13 (Reimer et al. 2013). An age-depth model was produced using the Bayesian software Bacon (Blaauw \& Christen 2011), which assumed a piece-wise linear accumulation of the lake sediment constrained by prior information on the lake's accumulation rate and its variability between neighbouring depths.

\section{Results}

Lithological characteristics of the core FA-1 
The basal succession of the core FA-1 (Fig. 2) is composed of massive carbonate clayey eluvium (26.0 - $20.8 \mathrm{~m}$ depth). This is overlain by coarse sand at $20.8-19.8 \mathrm{~m}$ depth, followed by thinly and rhythmically-laminated silt and clay, interrupted at $15.53-15.45 \mathrm{~m}$ depth by a sand layer. The clayey and silty material is probably fluvial in origin and indicates inflow of the Nile water during the summer floods, whereas sandy and carbonate material could be derived by local heavy rainfalls from the vicinity of the lake (cf. Flower et al. 2012). The thinly laminated part of the core $(19.76-13.05 \mathrm{~m}$ depth) is composed of carbonate, diatomite and clayey laminae. Light laminae contain almost exclusively planktonic diatoms of the genera Stephanodiscus and Aulacoseira (relative abundance of 60-90\%). There are also very thin $(\sim 0.5 \mathrm{~mm})$ layers of amorphic organic matter.

A considerable lithological change occurs at $13.1 \mathrm{~m}$ depth (Fig. 2). Rhythmites are replaced by massive silt and clay with irregular, thick diatomite and ferruginous interbeds. At $12.8-10.0 \mathrm{~m}$ depth, the core is composed mostly of silty clay with white-grey interbeds, 1-5 mm thick, containing predominantly Aulacoseira granulata and Stephanodiscus diatoms (90$95 \%)$. Starting from depths of $\sim 8 \mathrm{~m}$ upwards, the core is composed of massive silty clay with sandy interbeds at $\sim 7.6 \mathrm{~m}$ and $7.2 \mathrm{~m}$. At $6.9-6.3 \mathrm{~m}$ they are replaced by silty clay with dispersed organic matter and irregular crystals of gypsum.

Steel-gray silty clay is characteristic at depth $6.0-5.6 \mathrm{~m}$ and it is occasionally interbedded with organic and white-gray laminae (Fig. 2). At depth $5.5-4.0 \mathrm{~m}$ the core is composed of massive gray-brown silty clay. Above, at $4.0-3.4 \mathrm{~m}$ there is a loose shell sediment with pieces of malacofauna mixed with gray sludge silt. This deposit resembles modern shell accumulations on the present beach. The overlying sediments at $3.4-1.9 \mathrm{~m}$ depth are composed of massive gray-brown silty clay with gravel grains, several $\mathrm{mm}$ in diameter (depth $2.57-2.65 \mathrm{~m}$ ). At $2.2 \mathrm{~m}$ depth silt is predominated by angular grains of quartz. 
Age model and sedimentation rate

249 Most samples for radiocarbon dating were collected from layers rich in organic matter, except for the lowermost part (Table 1). In the lower part of the core (depth $18.5-13.0 \mathrm{~m}$ ) there are regular and very thin laminae of dark brown amorphous organic matter intercalated with diatom and calcite laminae. Other fragments of the core contain laminated deposits separated by either sandy-silty massive or deformed series (cf. Fig. 2). Several successive laminae could be deposited in a single year (cf. Marks et al. 2016).

Organic material, usually associated with calcite layers, indicates a predominance of inner-lake biological processes including a high algal productivity (cf. Flower et al. 2012). In the upper 13.0 - $2.0 \mathrm{~m}$, less regular (see Marks et al. 2016), bulk samples were collected for radiocarbon dating, composed of silty clay with varied admixture of organic matter. We assumed that this organic matter was produced by both biogenic production within the lake and delivery of allochthonous material, both alluvial from the Nile during summer floods and terrestrial material eroded during occasional heavy rainfall in winter (see Flower et al. 2012).

Such significant redeposition could result in a hard water effect and incorporation of old carbonates and other carbon sources. We note that the radiocarbon dates show a considerable spread at this section of the core (Fig. 3), whereas they appear much more coherent within the other sections.

Calcite is present in the laminated deposits and it means that a hard water effect is very likely on the authochonous organic material as well. We have not done any exact estimation of the hard water effect but it seems obvious that it is higher in the lower part of the core, because of intensive redeposition of carbonates from the area around the lake. This effect is considerably smaller in the laminated part of the section, especially as we selected the 
absent the hard water effect can be higher as the bulk samples were mostly collected for the radiocarbon dating.

Construction of the age-depth model of the lake sediments required an assessment of several agents that could disturb constant accumulation of deposits. Disturbances could result both from sedimentary and post-sedimentary processes, including varying rates of deposition, erosional and omission surfaces, progressive or varied compaction and impacts of bioturbation. In the examined core some of these factors could be ignored such as effects of compaction (because of highly homogeneous sediment in the analyzed section) and bioturbation (no benthic organisms were detected) (e.g. Björck \& Wohlfarth 2001). A potentially important factor was a varied influx of sediment to the lake from the adjacent area and by the Nile. We therefore used Bacon (Blaauw \& Christen 2011), a flexible age-depth routine which explicitly models the accumulation rate and its variability, and which uses student-t distributions with wide tails to accommodate dating scatter. We used all the default settings, except for the section thickness which was set at $20 \mathrm{~cm}$ given the length of this core. Bacon used the IntCal13 curve (Reimer et al. 2013) to calibrate the radiocarbon dates.

Sedimentation rate in the lake was estimated based on counting of the laminae, using the high-resolution photographs of the core. Every set of laminae (diatom, mineral and organic mud) was assumed to represent a single year. The reconstructed sedimentation rate was the lowest in the initial phase of the lake, represented by the finest and most regular lamination at 19.8 - $18.9 \mathrm{~m}$ depth, with average annual sedimentation rate of $1.4 \mathrm{~mm}$ (Fig. 4). Uniform and then slightly rising sedimentation rate of $2.7-7.7 \mathrm{~mm} \mathrm{a}^{-1}$ occurs at $18.4-14.1 \mathrm{~m}$ depth Sedimentation rate has risen consequently above the depth of $14.1 \mathrm{~m}$ and reached maximum of $37.7 \mathrm{~mm} \mathrm{a}^{-1}$ at $9.08-8.5 \mathrm{~m}$, indicating an unstable sedimentary environment. At depth 18.25 - $12.50 \mathrm{~m}$ twelve samples were radiocarbon dated, both from organic agglomerations and bulk samples with dispersed organic matter (Table 1). Contents of total organic carbon 
are the highest and of carbonates are the lowest in this part of the core and all ages are almost in perfect superposition, presumably indicating that neither substantial disturbances in carbon content nor significant redeposition have impacted sedimentation in this part of the core.

Taking into account the above considerations and other data, tentative chronological. boundaries were determined for the core FA-1 (Fig. 3). Very low contents of total organic carbon below $19.7 \mathrm{~m}$ depth and much inorganic carbonate between 19.5 and $19.0 \mathrm{~m}$ depth made the age model tentative for these parts of the core.

\section{Lake salinity and geochemical. indicators of climate change}

Variations of salinity in the lake could directly reflect incoming water sources and evaporation. Among the former the most important were intermittent inflows of the Nile water, because impermeable bedrock and small annual precipitation made eventual feeding by groundwater doubtful (Flower et al. 2012). Palaeosalinity of the lake was determined via measurement of contents of water-soluble ions in the sediment. The lake water was found to have evolved generally from freshwater to saltwater setting but it was not a straightforward change. This went through several important stages of sedimentation: from carbonate to sodium, to sulphur and then to the final desiccated lake basin. Analytical. results from the core FA-1 sediments indicate at least 6 phases (Fig. 5), based on varying contents of ions in the sediments:

Phase 1 (>19.8 m depth, >9.8 cal. ka BP): except of $\mathrm{NH}_{4}{ }^{+}$which was derived mainly from a soil release, the lowest values of all anions were due to drier climate and indicated a desiccated lake basin.

Phase $2\left(19.8\right.$ - 13.1 m depth, $\sim 9.8-6.2$ cal. ka BP): contents of $\mathrm{NH}_{4}{ }^{+}$and $\mathrm{NO}_{3}{ }^{-}$increased dramatically upwards but with minor increases for $\mathrm{Cl}^{-}, \mathrm{Na}^{+}, \mathrm{Mg}^{2+}$ and $\mathrm{Ca}^{2+}$ (Fig. 5), suggesting a relatively strong nitrification due to enhanced productivity of the lake 
dominated by freshwater setting. Therefore, the freshwater environment implies a hydrological linkage with the Nile, although minor fluctuations in ion contents suggested certain irregularities over time.

Phase 3 (13.1 - $12.4 \mathrm{~m}$ depth, 6.2 - 5.9 cal. ka BP): sharp increases of $\mathrm{Cl}^{-}, \mathrm{Mg}^{2+}, \mathrm{Ca}^{2+}$ and $\mathrm{Na}^{+}$indicated rapid rise in lake water salinity (Fig. 5). This implies a dry environment setting and notably a restricted hydrological. connection with the Nile.

Phase 4 (12.4 - 7.9 m depth, 5.9 - 4.4 cal. ka BP) - ion contents were kept almost stable. This implies slight salinization resulting from moderate connection to the Nile.

Phase 5 (7.9 - $4.0 \mathrm{~m}$ depth, $4.4-1.5$ cal. ka BP): evident increase of all ion contents at the beginning (Fig. 5) indicates enhanced salinization due to lack of precipitation and/or input from the Nile.

Phase 6 (4.0 - $1.9 \mathrm{~m}$ depth, <1.5 cal. ka BP): all anions contents were kept lower than previously. This suggests a sound connection of the lake to the Nile.

\section{Diatom phases}

Diatoms are abundant and moderately to well-preserved throughout the core FA-1 from a depth 19.8 to $6.5 \mathrm{~m}$, and relatively frequent toward the top but with some samples containing poorly preserved sporadic diatoms (depths: $6.3-5.9,5.7-5.6,4.9-4.8$ and $4.2-4.0 \mathrm{~m}$ ). A low diversity with 112 species is recognized. Planktonic taxa are the most abundant, reaching to $98 \%$ of the total assemblage, while benthic and epiphytic forms are very rare and sparsely distributed. Aulacoseira with 11 species, followed by Stephanodiscus with 9 species are the most dominant planktonic genera, with Cyclostephanos and Cyclotella species distributed frequently (Fig. 6).

The diatom spectra are dominated by riverine taxa including Aulacoseira granulata, A. italic, A. ambigua and Stephanodiscus spp. Abundant peaks of these taxa are intepreted as an 
347 indication of increased discharge of the Nile water into the lake. The diatom assemblage 348 indicative of high stand lake level and increased nutrient availability persisted in the 349 Holocene but lower concentrations or lack of diatom valves at some depths $(6.3-5.6,4.95-$ $3504.8,4.9,4.2-4.0 \mathrm{~m}$ ) suggest lower diatom productivity. The upper part of the core (depth 4.0 $351-2.0 \mathrm{~m}$ ) is completely barren of diatom frustules, reflecting marked environmental changes 352 in the lake, connected with transition from freshwater through brackish to saline conditions.

353 Stratigraphic distribution of recorded planktonic taxa samples led to recognition of 5 types of 354 diatom ecozones in the studied core that is Aulacoseira spp., Stephanodiscus spp., 355 Aulacoseira-Stephanodiscus spp., Cyclostephanos dubius and Aulacoseira spp.-Cyclotella 356 meneghiniana (Fig. 6). 
358 Aulacoseira spp. assemblage. - This assemblage is recorded 9 times (Fig. 6), being

359 dominated by Aulacoseira granulata and accompanied commonly by A. granulata var. 360 angustissima, A. ambigua, A. italica and A. islandica. There are low contents of other 361 planktonic taxa. Aulacoseira granulata was a freshwater planktonic and alkaliphilous 362 species, common in eutrophic water of higher temperature (Hustedt 1957; Ehrlich 1973; 363 Stoermer et al. 1975). The Aulacoseira species indicates high growth requirements for silicon 364 and demanded high silica content in water (Kilham \& Kilham 1971), presumably in different 365 combinations of $\mathrm{P}$ and light (Kilham et al. 1986). However, Aulacoseira species are non366 competitive, so their wide distribution normally coincided with low concentration of other 367 diatoms (Wolfe et al. 2000). Aulacoseira taxa are also used as indicators of warmer climate, 368 which may have led to wind-induced mixing in the lake, higher input of humic substances 369 and increased precipitation. They suggest stabilized conditions, remaining wet and windy 370 with increased turbulence and upwelling in the lake, typical of a late phase of the Nile flood 371 cycle (Zalat 1995). Aulacoseira species were presumably most dominant in summer and 372 relatively common in spring. Their predominance indicates summers with high silica 373 concentration. Maximum abundances of Aulacoseira granulata associated with other 374 Aulacoseira species and decreased abundance of Stephanodiscus and Cyclotella species 375 could reflect a freshwater lake with relatively high level due to nutrient-rich influx from the 376 Nile during a wet warm period. 
Stephanodiscus spp. assemblage. - Seven such assemblages are recorded (Fig. 6). They have the highest abundance of planktonic freshwater Stephanodiscus species (60-83\%), including S. rotula, S. agassizensis, S. minutulus, S. aegyptiacus, S.neoastraea, S. alpinus, S. hantzschii and S. niagarae. Other planktonic taxa are rare. Stephanodiscus species are known to occupy slightly alkaline and eutrophic freshwater with low silica content (Gasse 1986; Kilham et al. 1986; Zalat \& Servant-Vildary 2007). Stephanodiscus taxa were dominant in winter and spring when increased turbulence could suspend these relatively heavy diatoms, therefore they could denote moist winters and springs with active circulation (Bradbury 1992; Bradbury et al. 2004). Dominance of small and intermediate-sized Stephanodiscus species (S. minutulus, S. hantzschii, and S. agassizensis) characterized spring bloom when nutrient loading was related to spring runoff, along with Aulacoseira granulata. The increased abundance of planktonic Stephanodiscus species reflects a high lake level and increased nutrient loading to the lake with low $\mathrm{Si}$ and high $\mathrm{P}$ supply rates prevailing at time of deposition (Zalat 2015).

Aulacoseira-Stephanodiscus spp. assemblage. - This assemblage is recorded three times in the core FA-1 (Fig. 6) and is characterized by common occurrence of Aulacoseira spp. and Stephanodiscus spp. (80-90\%). Other planktonic taxa are distributed sporadically. This diatom assemblage is indicative of a high stand lake level with enhanced nutrient availability by repeated inflows of the Nile to the lake at the transition from spring to summer.

Cyclostephanos dubius assemblage. - This assemblage is observed in 3 thin zones (Fig. 6). It is characterised by abundance of Cyclostephanos dubius (40-55\%), accompanied by Aulacoseira spp., which is more abundant than Stephanodiscus taxa. Other planktonic taxa as Cyclotella kützingiana and C. ocellata are distributed frequently. Cyclostephanos dubius is a 
403 pelagic taxon, common in flowing and stagnant freshwater in a coastal area, of low 404 conductivity and low to medium alkalinity $(\mathrm{pH}=7.6-8.9)$. The diatom assemblage includes 405 common occurrences of Aulacoseira spp., Cyclostephanos dubius and Stephanodiscus taxa, 406 indicating a high stand lake level with clear dominance of eutrophic freshwater conditions 407 and slightly higher salinity and alkalinity in summer.

408

Aulacoseira spp. - Cyclotella meneghiniana assemblage. - The zone was recorded only once, with a thickness of about $0.5 \mathrm{~m}$ (Fig. 6) and is characterised by high abundance of Aulacoseira spp. and Cyclotella meneghiniana. Other planktonic taxa including Stephanodiscus spp. and Cyclotella spp. are rare. Cyclotella meneghiniana is a facultative 413 planktonic taxon typical for moderately alkaline conditions (Hecky \& Kilham 1973; 414 Richardson et al. 1978), in coastal and estuarine locations with water of varied chemistry 415 (Trigueros \& Orive 2000; Tibby \& Reid 2004). Its most favourable development occurs at $\sim 20^{\circ} \mathrm{C}$ but it is eurythermal (Gasse 1986). This species was reported from slightly brackish water of coastal Egyptian lakes, being dominant in spring and at the beginning of summer at water temperatures of $29-31^{\circ} \mathrm{C}$ (Zalat \& Servant-Vildary 2007). Common occurrence of Cyclotella meneghiniana with high abundances of Aulacoseira species and frequently to low amounts of Stephanodiscus taxa reflect warm eutrophic freshwater conditions with slight increased salinity and alkalinity.

Mollusc and ostracod indicators

424 Altogether 10 taxa of molluscs (6 snails and 4 bivalves) and 8 taxa of ostracods are recognized in the FA-1 core (Table 2). Molluscs are represented by 735 specimens, but with 1-8 taxa and from 2 to 726 specimens in a single sample. Shells are abundant in the upper

427 part of the core $(4.0-3.5 \mathrm{~m}$ depth $)$ and their assemblage is predominated by brackish species, 
among which the most numerous is Hydrobia ventrosa and Cerastoderma glaucum. These species are accompanied by euryhaline snails Pirenella conica and Hinia costulata and three freshwater snails, the most abundant of which was Melanoides tuberculata (Table 2). The lowermost samples $(18.9$ - $18.7 \mathrm{~m}$ depth) contain very scarce shell material with only few specimens of the freshwater endemic snail Valvata nilotica and fragments of saline bivalves Abra ovata and Cerastoderma sp. (Table 2).

Ostracods with 8 taxa and 2872 specimens are more abundant than molluscs. There are 1-6 taxa and from 2 to 626 specimens in a single sample, with the lowest number at depths of 18.05, 17.95 - 17.9 and 17.0 - $6.0 \mathrm{~m}$ (Table 2). Most ostracod species have wide ecological. tolerance (Sywula 1974; Park \& Martens 2001; Keatings et al. 2010). Samples from 18.9 $18.7 \mathrm{~m}$ depth are dominated by Herpetocypris sp. (juveniles and damaged valves) and Gomphocythere sp., most common and characteristic for a sublittoral zone of a freshwater lake (e.g. Park \& Martens 2001; Boomer \& Gearey 2010; Cohen et al. 2013). Numerous Candona neglecta and Limnocythere inopinata tolerate both fresh and salty waters, and various depth conditions. Cyprideis torosa dominate at $18.0 \mathrm{~m}$ and $4.0-3.5 \mathrm{~m}$ depth. It is the most frequent in calm, near-shore zones of a brackish water body (cf. Sywula 1974; Neale 1988). The valves of this species are all without the nodes (cf. Keatings et al. 2010). It seems that most ostracods represent a near-shore zone and they were common at depths when a coastline was near the drilling site.

The occurrence of Valvata nilotica and Gomphocythere sp. at 18.9 - $18.7 \mathrm{~m}$ depth indicates a freshwater environment. Single fragments of shells of salt-water taxa Abra ovata and Cerastoderma sp. were probably redeposited during drilling from the uppermost part of the core. Scarce molluscs and abundant ostracods with Gomphocythere sp., Candona neglecta and Limnocythere inopinata could provide evidence for somewhat deeper part of the lake in the lower part of the succession. A small number of complete carapaces $(2.4-28.0 \%)$ 
453

454

455

456

457

458

459

460

461

462

463

464

465

466

467

468

469

470

471

472

473

474

475

476

477

point out to presumably high-energy conditions (cf. Keatings et al. 2010). Variable relations of Cyprideis torosa and Limnocythere inopinata at 18.0, 5.0 and 4.0 - $3.5 \mathrm{~m}$ depth could be connected with changes of water chemistry in the Qarun Lake (cf. Keatings et al. 2010). The isolated high count of $C$. torosa at $18 \mathrm{~m}$ depth (Table 2) is especially worth noting, as it implies very short, probably decadal scale episode with higher salinity. C. torosa predominate in waters with $\mathrm{Na}^{+}$and $\mathrm{Cl}^{-}$ions, whereas L. inopinata prefer carbonatebicarbonate rich waters with $\mathrm{Na}^{+}$and low content of $\mathrm{Ca}^{2+}$. These changes can be connected with farming in the region and/or changes of the Nile supply (cf. Keatings et al. 2010). Abundant Cyprideis torosa and expansion of molluscs typical of saline waters at $4.0-3.5 \mathrm{~m}$ could reflect an increased salinity and shallow-water conditions in the lake. Distinct predominance of Hydrobia ventrosa and Cyprides torosa indicate a drop of water level and salinity of $14-25 \%$ as no nodded valves of C. torosa occur (e.g. Neale 1988; Keyser \& Aladin 2004; Götting 2008; Welter-Schultes 2012). A considerable amount of complete ostracod carapaces (45\%) and occurrence of Pirenella conica support steady sedimentation in a shallow lake (Taraschewski \& Paperna 1981; Boomer et al. 2003; Keatings et al. 2010). An admixture of freshwater species could suggest some shell mixing, but most of these species co-occurred with brackish taxa in other Egyptian lakes. Melanoides tuberculata and Cleopatra bulimoides were even listed amongst brackish snails (e.g. Sattmann \& Kinzelbah 1988).

\section{Development of the Faiyum Lake in the Holocene}

Multi-proxy investigations of the core FA-1 (Figs 4-6, Table 2) and comparison of their results with other cores in the Qarun Lake area (cf. Baioumy et al. 2010, 2011; Flower et al. 2012, 2013) supplied with high-resolution palaeoclimate data indicate several phases of the Faiyum Lake development during the Holocene (Fig. 7). The lake was initially a freshwater 
lake, but then went through brackish to saline conditions. These changes were accompanied by a fluctuating water level in the lake (interpreted from shifts of lake shore and varying salinity), strictly combined with more intensive or reduced annual influx from the Nile.

\section{>10.0 cal. ka BP: pre-lake deposition}

Weathered mantle of the Late Eocene marls and limestones from the adjacent area were the main source of yellow-brown massive carbonate clay (depth $26.00-20.8 \mathrm{~m}$ ) that could be redeposited by occasional sheet-floods to the central part of the basin. These deposits contain inserts and concentrations of clayey silt, sand, gravel and dispersed organic matter, indicating influx of mineral material in a semi-dry climate from the surroundings. There was no hydrological connection with the Nile, because of lack of any, even ephemeral lake sediments.

\section{0 - 9.8 cal ka. BP: initial lake}

A freshwater lake appeared in the Faiyum Oasis at about 10.0 cal. ka BP (cf. Fig. 7), confirming the earlier suggestion of Flower et al. (2012). The lake had presumably a quasipermanent seasonal connection with the Nile at $17 \mathrm{~m}$ a.s.l. (Hassan et al. 2011) as indicated by deposition of gray silt (20.8 - $19.8 \mathrm{~m}$ depth). Intermittent influx of terrestrial sandy material as well as gradually decreasing and varied contents of $\mathrm{NH}_{4}{ }^{+}, \mathrm{NO}_{3}{ }^{-}, \mathrm{Mg}^{2+}$ and $\mathrm{Ca}^{2+}$ suggests erosion and redeposition of covering deposits and soils in the surroundings (Fig. 5).

Termination of this phase is represented by a greenish-gray sandy mud intercalated with bedded sand with taxa of Chara that indicate shallow $(0.5-4.0 \mathrm{~m})$, fresh to slightly brackish lake and increased evaporation during drier periods (Zalat 1995, 2015). Regular inflows of the Nile water in late spring and early summer are evidenced by predominant diatoms of the Aulacoseira spp. assemblage zone (Fig. 6). They were blooming in summer, what could result 
503

in strong nitrification and high primary productivity in the lake. The lake was freshwater,

504 more silica in late spring and summer.

506 slightly alkaline $(\mathrm{pH}=7-8)$ and eutrophic, and due to increasing primary productivity - with $9.8-8.6$ cal ka. BP: freshwater deep lake

A regularly laminated part of the core (depth $19.8-18.1 \mathrm{~m}$ ) indicates a stabilized environment of the lake (Figs 4, 7). Organic-rich clayey silt laminae reflect varied seasonal sediment input to the lake. Thin $(0.5 \mathrm{~mm})$ layers of amorphic organic matter could be due either floods of the Nile or a high biogenic production in the lake. Dark laminae are deposited in winter and white laminae reflect high diatom productivity during summer (cf. Flower et al. 2012; cf. Marks et al. 2016). This phase of lake development started with a rapid replacement of the planktonic Aulacoseira by the Stephanodiscus diatoms. The latter indicates increased winter and spring wind-induced water turbulence and diatom blooming in spring (cf. Bradbury 1975, 1988). Much P, peaks of $\mathrm{Ca}^{2+}$ and $\mathrm{NO}_{3}{ }^{-}$are recorded (Figs 5, 6). The lake was generally freshwater, eutrophic and slightly alkaline, with a high water level. The sedimentation rate doubled from 1.4 to $2.8 \mathrm{~mm} \mathrm{a}^{-1}$ (Fig. 4). Enhanced nutrient availability resulted in strong nitrification and high productivity. Silica content was high in spring and summer (Fig. 6). Peaks of $\mathrm{K}^{+}$and $\mathrm{NH}_{4}{ }^{+}$contents, rapid rises of $\mathrm{Na}^{+}$and $\mathrm{Mg}^{2+}$ are recorded, indicating salted lake water occasionally happening (Fig. 5).

\section{$8.6-8.4$ cal ka. BP: slightly brackish shallow lake}

The laminae of clayey silt (depth $18.1-17.7 \mathrm{~m}$ ) are strongly deformed, presumably due to unstable sedimentary environment. It was a short episode of increased salinity indicated by higher contents of $\mathrm{Na}^{+}, \mathrm{Ca}^{2+}, \mathrm{Mg}^{2+}$ and $\mathrm{Cl}^{-}$(Fig. 5) and high frequency of Cyprideis torosa (Table 2), accompanied by a drop of water level. Regular inflows of the Nile water in late 
spring and early summer are evidenced by predominant diatoms of the Aulacoseira spp. assemblage (Fig. 6), blooming in summer. A distinct rise in contents of $\mathrm{NH}_{4}{ }^{+}$occurred at the end, indicating input of washing-out from soils in the surroundings of the lake.

\section{$8.4-6.2$ cal. ka BP: freshwater deep lake}

This phase is expressed by thinly laminated clayey silts (depth $17.7-13.1 \mathrm{~m}$ ), reflecting varied seasonal sediment input to the lake. Dark laminae represent winter deposition, mostly of terrigenous derivation and white laminae reflect high diatom productivity in summer (Flower et al. 2012; cf. Marks et al. 2016). Thin (0.5 mm) layers of amorphous organic matter could be deposited either during floods of the Nile or due to intensive biogenic production in the lake. An increased influx of sand from the surroundings is recorded at about $8.2 \mathrm{cal}$. ka BP (17.4 m depth) and $7.2 \mathrm{cal}$. ka BP (15.45 - $15.53 \mathrm{~m}$ depth). The former could reflect a climate crisis connected roughly with the $8.2 \mathrm{ka}$ BP event (cf. Rohling \& Pälike 2005). The sedimentation rate had been slightly rising from 2.7 to $3.7 \mathrm{~mm} \mathrm{a}^{-1}$ at the beginning and reached $6.9 \mathrm{~mm} \mathrm{a}^{-1}$ at the end (Fig. 4). An enhanced nutrient availability in the lake indicates regular inflows of the Nile water in late spring and early summer. Peaks of $\mathrm{NO}_{3}{ }^{-}$and $\mathrm{NH}_{4}{ }^{+}$are due to increased content of organic matter, presumably washed into the lake from the surroundings. Diatoms of the Aulacoseira spp. assemblage (Fig. 6) bloomed in summer, which could result in strong nitrification, enhanced silica content and high primary productivity in the lake. The lake was slightly alkaline $(\mathrm{pH}=7-8)$ and eutrophic, with a high water level. Archaeological. sites of the Neolithic Faiyum A Culture located along the shoreline prove that the lake reached its maximum extension (Fig. 8) and depth, with its water level at about $20 \mathrm{~m}$ a.s.l. (Wendorf \& Schild 1976; Wenke et al. 1988). $\mathrm{Cl}^{-}$and $\mathrm{Na}^{+}$ were slightly decreasing in the second part of the phase (Fig. 5), suggesting a rising water 
552

553

554

555

556

557

558

559

560

561

562

563

564

565

566

567

568

569

570

571

572

573

574

575

576

level. $\mathrm{FeS}_{2}$ formed occasionally, presumably indicating reductive conditions, but the accompanying strong nitrification allowed for high productivity in the lake.

\section{2 - 5.7 cal. ka BP: shallow brackish to freshwater lake}

Abrupt rise of $\mathrm{Cl}^{-}, \mathrm{Na}^{+}, \mathrm{Mg}^{2+}$ and $\mathrm{Ca}^{2+}$ and less regular lamination of lake sediments (13.1 $11.7 \mathrm{~m}$ depth) indicate restricted hydrological connection with the Nile. The lake had been periodically brackish (Fig. 5) and the water level dropped significantly (cf. Baioumy et al. 2011). The reservoir became smaller and shallower, with predominance of Aulacoseira spp. assemblage (Fig. 6) but sporadic thick diatom layers in the sediments could indicate extremely huge occasional floods. Intensive influx of material from the surroundings (also from exposed older lake deposits) as is indicated by interbeds of sand and silt, slightly higher contents of $\mathrm{NO}_{3}{ }^{-}$and $\mathrm{SO}_{4}{ }^{2-}$, with local concentration of $\mathrm{Fe}$ compounds due to drying of the peripheral area. The sedimentation rate was $9.6 \mathrm{~mm} \mathrm{a}^{-1}$ (Fig. 4). Human settlements in the Faiyum Oasis had disappeared but the Pharaonic civilization developed in the Nile valley in Egypt (Wendorf \& Schild 1976; Hassan et al. 2012).

\section{$5.7-4.4$ cal. ka BP: shallow freshwater lake with brackish episodes}

At the very beginning and at the end of this phase the littoral zone of the lake became restricted as mostly pelagic and oligosaprobic (mesosaprobic) Cyclostephanos dubius diatoms occurred (Fig. 6). Deposition of grey-brown clayey silt (11.7 - $7.9 \mathrm{~m}$ depth) with irregular, thick $(1-5 \mathrm{~mm})$ diatomite prevailed, combined with few organic laminae and ferruginous interbeds (Fig. 2). Rapid increase of terrestrial material is noted around $5.0-4.8$ cal. ka BP. The sedimentation rate was $16.9-17.0 \mathrm{~mm} \mathrm{a}^{-1}$ at the beginning and then rapidly increased to the maximum of $37.7 \mathrm{~mm} \mathrm{a}^{-1}$ (Fig. 4), presumably due to increasing supply of material from the surroundings and the Nile. During most of this time interval $(5.6-4.6$ cal. ka BP) the lake 
577 was slightly alkaline $(\mathrm{pH}=7-8)$ and eutrophic, with higher water level and wind-induced

578

579

580

581

582

583

584

585

586

587

588

589

590

591

592

593

594

595

596

597

598

599

600

water mixing in winter. Aulacoseira and Stephanodiscus assemblages dominated, indicating intensive seasonal water circulation, enhanced nutrient availability with much $\mathrm{P}$ and seasonal influx of the Nile water. There was a short and weak brackish episode at about 5.1 cal. ka BP, indicated by small rises of $\mathrm{Ca}^{2+}, \mathrm{Mg}^{2+}, \mathrm{Na}^{+}, \mathrm{K}^{+}, \mathrm{SO}_{4}{ }^{2-}, \mathrm{NH}_{4}{ }^{+}, \mathrm{NO}_{3}{ }^{-}$and $\mathrm{Cl}^{-}$(Fig. 5).

\section{4 - 3.0 cal. ka BP: shallow brackish and partly desiccated lake}

The deposition in the lake became considerably varied $(7.9-6.0 \mathrm{~m}$ depth): at first, with significant input of sand, presumably by sheet floods caused by occasional heavy rainfalls in the surroundings (Welc \& Marks 2014). Intensive wind-induced water mixing in winter could have resulted in maximum abundance of Stephanodiscus species ( $>70 \%$ of the total diatom assemblage) (Fig. 6). It reflects a presence of a slightly alkaline $(\mathrm{pH}=7-8)$ and eutrophic lake with water level rise to about $12 \mathrm{~m}$ a.s.l. (Fig. 8) and low contents of $\mathrm{Na}^{+}, \mathrm{K}^{+}, \mathrm{Cl}^{-}$and $\mathrm{NO}_{3}^{-}$ but enhanced nutrient availability, much $\mathrm{P}$ and low silica. The lake was basically cut-off from the Nile but deposition of clayey silt suggests that rare inflows were possible, presumably as suggested by common planktonic Aulacoseira diatoms that bloomed in summer. The first part of this phase was generally dry and it was expressed by progressing desiccation of shallower parts of the lake as indicated by rising contents of $\mathrm{Mg}^{2+}, \mathrm{Ca}^{2+}$ and $\mathrm{SO}_{4}{ }^{2-}$ (Fig. 5) and admixture of gypsum in lake sediments. The lake level could be dramatically low at that time (Baioumy et al. 2010). Such unfavourable regional climate and environmental conditions at the beginning of this phase could be referred to the $4.2 \mathrm{ka}$ event that resulted in a collapse of the Egyptian Old Kingdom (Hassan 2007). At the termination of this phase at about 3.2 cal. ka BP, the lake sediments were completely devoid of diatoms and dominated by sand from the surroundings (Fig. 6). 


\section{0 - 1.5 cal. ka BP: brackish to freshwater lake}

A more regular seasonal water supply from the Nile returned presumably at the beginning of this phase when the lake contained much silica and planktonic Aulacoseira were common in spring (Fig. 6). The sedimentary environment became more stable with deposition of silt (6.0 $-4.0 \mathrm{~m}$ depth), locally interbedded with organic and diatomite laminae, sandy layers and dispersed organic matter. Admixture of pyrite indicates a reducing environment and possibly, also a deeper lake. The sedimentation rate was $13.75 \mathrm{~mm} \mathrm{a}^{-1}$ (Fig. 4). However, the following very low diatom content or even lack of diatoms in the sediments were combined with lower productivity in the lake itself (Fig. 6). The lake had been occasionally brackish as indicated by dominance of Aulacoseira spp. - Cyclotella meneghiniana assemblage, characteristic of warm, eutrophic and slightly brackish water conditions (Fig. 6) what is indicated by rising contents of $\mathrm{Cl}^{-}, \mathrm{NO}_{3}{ }^{-}, \mathrm{SO}_{4}{ }^{2-}, \mathrm{Na}^{+}, \mathrm{K}^{+}, \mathrm{Mg}^{2+}$ and $\mathrm{Ca}^{2+}$ (Fig. 5). Contents of $\mathrm{Ca}^{2+}, \mathrm{Mg}^{2+}, \mathrm{Na}^{+}$, $\mathrm{SO}_{4}{ }^{2-}, \mathrm{Cl}^{-}$and $\mathrm{NO}_{3}{ }^{-}$were decreasing at $2.3-1.8$ cal. ka BP (Fig. 5), showing desalinizing lake water, presumably due to higher water supply from the Nile via the man-made channel in the Ptolemaic Period (Garbrecht 1994). The lake water level was at about the sea level (Fig. 8). Increased nutrients in the lake and probably wind as well induced winter circulation favoured blooming of Stephanodiscus in spring but diatoms completely disappeared at the termination of this phase.

\section{5 - 1.2 cal. ka BP: shallow brackish-saline lake}

Deposition of beach loose shell sediment occurred (4.0 - $3.4 \mathrm{~m}$ depth), mixed with grey sludge silt (Fig. 2). Gastropod and ostracod assemblages indicate a drop of water level and salinity of $14-25 \%$, with carbonate-bicarbonate rich water, seemingly due to farming and changes in water supply from the Nile. 


\section{$<1.2$ cal. ka BP: shallow saline lake}

There was a deposition of massive grey-brown clayey silt (3.4 - $1.9 \mathrm{~m}$ depth) with admixture of gravel and angular quartz grains, typical of a shallow and near-shore environment. Lower contents of $\mathrm{Mg}^{2+}, \mathrm{Ca}^{2+}, \mathrm{Na}^{+}$and $\mathrm{Cl}^{-}$, and rise of $\mathrm{K}^{+}$are recorded (Fig. 5). Recent environmental transformations of the lake were presented by Flower et al. (2006).

\section{Conclusions}

The core FA-1 from a beach of the Qarun Lake in the Faiyum Oasis with fine-laminated lake sediments supplied a continuous high-resolution record of environmental and climate changes through the Holocene. We demonstrated at least partly a palaeoenvironmental record of the Qarun Lake sediments, a potential of which was already estimated by Flower et al. (2012). A multi-proxies analysis enabled us to establish the age model and transformation of the lake in the Holocene. Our results confirm that a permanent lake in this area appeared at about $10 \mathrm{cal}$. ka BP but then its evolution went through several freshwater and brackish phases, starting from carbonate-dominant through $\mathrm{Cl}^{-}$and $\mathrm{SO}_{4}{ }^{2-}$ sedimentation, but it has never come to a total desiccation of the lake.

The Faiyum Oasis has been outside the Intertropical Convergence Zone (ITCZ) in the Holocene and therefore, its lake could survive due to inflows of the Nile water during flood seasons. The latter were most regular from 9.8 to 6.2 cal. ka BP when in a deep freshwater lake, a succession of fine-laminated sediments was formed, composed mostly of diatomite, mineral and organic silt, clearly indicating a seasonal change of lake productivity. This was significantly associated with regular inflows of the Nile water during flood seasons. Southward migration of ITCZ in northeastern Africa resulted in less regular inflows of the Nile water into the Faiyum Oasis. From 6.2 to 4.4 cal. ka BP the lake deposits were less regularly laminated, the water level dropped considerably and there were gradually more 
652 frequent brackish episodes. From 4.4 to 3.0 cal. ka BP the lake was brackish and considerably

653 less extensive, with water level at about $-20 \mathrm{~m}$ a.s.1., the sediments were massive but with 654 occasional inputs of sandy material washed from the surroundings due to local winter 655 rainfalls. The episode 3.0 to $1.5 \mathrm{cal}$. ka BP was a return to occasional freshwater conditions in 656 the lake, mostly due to a man-made canal dug at about 2.3 cal. ka BP that renewed a 657 hydrological connection with the Nile. Then the lake was gradually turned into a brackish and 658 finally, saline lake.

The examined FA-1 core created the reference age model of the Holocene climate

660

661

662

663

664

665

666

667

668

669

670

671

672

673

674

675

Acknowledgements. - The authors are grateful to the reviewer Paula J. Reimer and the anonymous reviewers for their insightful and helpful comments that greatly improved a previous version of the manuscript. The Editor-in-Chief Jan A. Piotrowski is thanked for his patience, thorough and constructive comments of the revised version. The project was implemented jointly by the Faculty of Geology of the University of Warsaw and the Institute of Archaeology of Cardinal Stefan Wyszyński University in Warsaw (Poland), Faculty of Science of the Kafr-el-Sheikh University (Egypt) and East China Normal University in Shanghai (China). The data were collected within the Nile Climate Change Project (NCCP) that was funded by the Polish National Science Centre in 2013-2016 (decision no. DEC2012/05/B/ST10/00558). The National Natural Sciences Foundation of China (NSFC, grant No. 41272194) supported financially a part of the geochemical. analyses. The authors are grateful to the authorities of the Kafrelsheikh University in Egypt for assistance in sampling and providing access to laboratory investigation. We thank to Dr. Zbigniew Szafrański from 
676 the Centre of Mediterranean Archaeology of the University of Warsaw for a logistic support 677 during fieldwork in Egypt.

678

\section{References}

680 Abell, P. I. \& Hoelzmann, P. 2000: Holocene palaeoclimates in northwestern Sudan: stable 681 isotope studies on molluscs. Global and Planetary Change 26, 1-12.

682 Abu-Zied, R. H., Keatings, K. W. \& Flower, R. J. 2007: Environmental controls on 683 foraminifera in lake Qarun, Egypt. Journal of Foraminiferal Research 37, 136-149.

684

Aleem, A. A. 1958: A taxonomic and palaeoecological investigation of the diatom flora of 685 the extinct Faiyum Lake (Upper Egypt). University of Alexandria Bulletin 2, 217-44.

Arz, H. W., Lamy, F., Patzold, J., Muller, P. J. \& Prins, M. 2003: Mediterranean moisture 687 source for an Early-Holocene humid period in the northern Red Sea. Science 300, 118121.

689

Baioumy, H., Kayanne, H. \& Tada, R. 2010: Reconstruction of lake-level and climate 690 changes in Lake Qarun, Egypt, during the last 7000 years. Journal of Great Lakes Research 36, 318-327.

692

Baioumy, H., Kayanne, H. \& Tada, R. 2011: Record of Holocene aridification (6000-7000 $\mathrm{BP}$ ) in Egypt (NE Africa): authigenic carbonate minerals from laminated sediments in Lake Qarun. Quaternary International 245, 170-177.

Ball, J. 1939: Contributions to the Geography of Egypt. 308 pp. Egyptian Survey and Mines Department, Cairo.

Beadnell, H. J. L. 1905: The Topography and Geology of the Fayum Province of Egypt. 101 pp. Survey Department, Cairo.

Björck, S. \& Wohlfarth, B. 2001: ${ }^{14} \mathrm{C}$ chronostratigraphic techniques in paleolimnology. In Last, W. M. \& Smol J. P. (eds.): Tracking Environmental Change Using Lake Sediments, 
Basin Analysis, Coring and Chronological. Techniques. Developments in Palaeoenvironmental Research 1, 205-245. Kluwer, Dordrecht.

Blaauw, M. \& Christen, J. A. 2011: Flexible paleoclimate age-depth models using an autoregressive gamma process. Bayesian Analysis 6, 457-474.

Blaauw, M., van Geel, B., Kristen, I., Plessen, B., Lyaruu, A., Engstrom, D. R., van der Plicht, J. \& Verschuren, D. 2011: High-resolution ${ }^{14} \mathrm{C}$ dating of a 25,000-year lakesediment record from equatorial East Africa. Quaternary Science Reviews 30, 3043-3059.

Boomer, I. \& Gearey, B. 2010: The occurrence of a new species of Gomphocythere (Ostracoda, Limnocytheridae) in the Holocene of SE Turkey: the northernmost record for the genus. Journal of Micropalaeontology 29, 115-118.

Boomer, I., Horne, D. J. \& Slipper, I. J. 2003: The use of ostracods in palaeoenvironmental studies, or what can you do with an ostracod shell? In Park, L. E. \& Smith, A. J. (eds.): Bridging the Gap: Trends in the Ostracode Biological. and Geological. Sciences. The Palaeontological. Society Papers 9, 153-179.

Bradbury, J. P. 1975: Diatom stratigraphy and human settlement in Minnesota. Geological. Society of America, Special Paper 171, 1-74.

Bradbury, J. P. 1988: A climate-limnological model of diatom succession for palaeolimnological. interpretation of varved sediments in Elk Lake. Journal of Palaeolimnology 1, 115-131.

Bradbury, J. P. 1992: Late Cenozoic lacustrine and climatic environments at Tule Lake, northern Great Basin, USA. Climate Dynamics 6, 275-284.

Bradbury, J. P., Colman, S. M. \& Dean, W. E. 2004: Limnological and climatic environments at Upper Klamath Lake, Oregon during the past 45,000 years. Journal of Palaeolimnology 31, 167-188. 
Brown, D. S. 1994: Freshwater Snails of Africa and their Medical Importance. 608 pp. Taylor \& Francis, London.

Caton-Thompson, G. \& Gardner, E. W. 1929: Recent work on the problem of Lake Moeris. Geographical. Journal 73, 20-60.

Caton-Thompson, G. \& Gardner, E. W. 1934: The Desert Faiyum. Vols I \& II. Royal Anthropological. Institute, London.

Cohen, A. S., van Bocxlaer, B., Todd J. A., McGlue, M., Michel, E., Nkotagu, H. H., Grove, A. T. \& Delvaux, D. 2013: Quaternary ostracodes and molluses from the Rukwa Basin (Tanzania) and their evolutionary and palaeobiogeographic implications. Palaeogeography, Palaeoclimatology, Palaeoecology 392, 79-97.

Dolson, J., El Barkooky, A., Wehr, F., Gingerich, P.D., Prochazka, N. \& Shann, M. (2002): The Eocene and Oligocene Paleo-Ecology and Paleo-Geography of Whale Valley and the Fayoum Basins: Implication for Hydrocarbon Exploration in the Nile Delta and EcoTourism in the Greater Fayoum Basin. AAPG/EPEX/SEG/EGS/EAGE Field Tripguidebook No. 7, 1-79. Cairo.

Ehrlich, A. 1973: Quaternary diatoms of the Hula Basin (northern Israel). Geological Survey of Israel bulletin 58, 1-39.

El Wakeel, S. K. 1963: A study of the bottom deposits of Lake Qarun. Egypt, 1, Mechanical. analysis. Bulletin of Faculty of Science of the Alexandria University 5, 33 - 60.

El-Sayed, E. \& Guindy, K. A. 1999: Hydrochemical investigations of El Fayium locality with special reference to the sulphate enrichment phenomenon in Lake Qarun. Bulletin of the Faculty of Science, Mansoura University 26, 1-21.

El-Shabrawy, G. M. \& Dumont, H. J. 2009: The Fayum Depression and its Lakes. Monographiae Biologicae 89, 95-124. 
749 Flower, R. J., Keatings, K., Hamdan, M. A. \& Hassan, F. A. 2013: Stephanodiscus Her. 750 Species from Holocene sediments in the Faiyum Depression (Middle Egypt). Phytotaxa $751 \quad 127,66-80$.

752 Flower, R. J., Keatings, K., Hamdan, M., Hassan, F. A., Boyle, J. F., Yamada, K. \& Yasuda, 753 Y. 2012: The structure and significance of early Holocene laminated lake sediments in the 754 Faiyum Depression (Egypt) with special reference to diatoms. Diatom Research 27, 127$755 \quad 140$.

756

757

758

759

760

761

762

763

764

765

766

767

768

769

770

771

772

773

Flower, R. J., Stickley, C., Rose, N. L., Peglar, S., Fathi, A. A. \& Appleby, P. G. 2006: Environmental changes at the desert margin: an assessment of recent paleolimnological records in Lake Qarun, Middle Egypt. Journal of Paleolimnology 34, 1-24.

Garbrecht, G. 1994: Historical water storage for irrigation in the Fayum Depression (Egypt). In Fahlbusch, H. (ed.): Historical Dams: Foundation of the Future Rest on the Achievements of the Past. International Commission on Irrigation and Drainage, New Delhi, 19-47.

Gasse, F. 1986: East African diatoms, taxonomy, ecological distribution. Bibliotheca Diatomologica 2, 1-201.

Ghamizi, M., Jørgensen, A., Kristensen, T. K., Lange, C., Stensgaard, A.-S. \& Van Damme, D. 2012: Cleopatra bulimoides. The IUCN Red List of Threatened Species. Version 2014.2. <www.iucnredlist.org>, accessed on 15 October 2014.

Ghamizi, M., Kristensen, T. K., Stensgaard, A-S. \& Van Damme, D. 2010: Musculium hartmanni. The IUCN Red List of Threatened Species. Version 2014.3. <www.iucnredlist.org>, accessed on 17 November 2014.

Goslar, T., Czernik, J. \& Goslar, E. 2004: Low-energy ${ }^{14}$ C AMS in Poznań Radiocarbon Laboratory, Poland. Nuclear instruments and methods in physics research section B: Beam Interactions with Materials and Atoms 223-224, 5-11. 
Götting, K-J. 2008: Meeres-Gehäseschnecken Deutschlands. Bestimmungsschlüssel, Lebensweise, Verbreitung. Die Tierwelt Deutschlands 80, 1-170. ConchBooks, Hackenheim.

Hassan, F. 2007: Droughts, famine and the collapse of the Old Kingdom: Re-Reading Ipuwer. In Hawass, Z. \& Richards, J. (eds.): Archaeology and Art of Ancient Egypt. Essays in Honor of David B. O. Connor 1, 357-377.

Hassan, F. A., Hamdan, M. A., Flower, R. J. \& Keatings, K. 2012: The oxygen and carbon isotopic records in Holocene freshwater mollusc shells from the Faiyum palaeolakes, Egypt: Their paloenvironmental and palaeoclimatic implications. Quaternary International 266, 175-187

Hassan, F., Hamdan, M., Flower, R. \& Tassie, G. 2011: Holocene geoarchaeology and water history of the Faiyum, Egypt. In Pirelli, R. (ed.): Natural and cultural landscapes in the Faiyum, 116-133. UNESCO, Cairo.

Hecky, R.E. \& Kilham, P. 1973: Diatoms in alkaline, saline lakes: ecology and geochemical. significance. Limnology and Oceanography 18, 53-71.

Hoelzmann, P., Gasse, F., Dupont, L. M., Salzmann, U., Staubwasser, M., Leuschner, D. C. \& Sirocko, F. 2004: Palaeoenvironmental changes in the arid and subarid-belt (Sahara-SahelArabian Peninsula) from 150 ka to present. In Battarbee, R. W., Gasse, F. \& Stickley, C. E. (eds.): Past Climate Variability Through Europe and Africa. Developments in Paleoenvironmental Research 6, 219-256.

Hustedt, F. 1930-1966: Die Kieselalgen. In L. Rabenhorst (ed.): Kryptogamenflora von Deutschland, Oesterreich und der Schweiz, Akademische Verlagsgesellschaft, Leipzig, 1: 1-920, 2: 1-845, 3: 1-816.

Hustedt, F. 1957: Die Diatomeenflora des Fluss-systems der Weser im Gebiet der Hansestadt Bremen. Abhandlungen der NaturwissenschaftlichenVerein zu Bremen 34, 181-440. 
799

800

Keatings, K., Holmes, J. A., Flower, R. J., Horne, D., Whittiker, J. E. \& Abu-Zied, R. H. 2010: Ostracods and the Holocene palaeolimnology of Lake Qarun, with special reference to past human-environment interactions in the Faiyum (Egypt). Hydrobiologia 654, 155 176.

Keyser, D. \& Aladin, N. 2004: Noding in Cyprideis torosa and its causes. Studia Quaternaria $21,19-24$.

Kilham, P. \& Kilham, S. S. 1971: Melosira granulata (Ehr.) Ralfs: morphology and ecology of a cosmopolitan freshwater diatom. Verhandlungen der Internationalen Vereinigung Limnologie 19, 2716-2721.

Kilham, P., Kilham, S. S. \& Hecky, R. E. 1986: Hypothesized resource relationships among African planktonic diatoms. Limnology and Oceanography 31, 1169-1181.

Kröpelin, S., Verschuren, D., Lezine, A.-M., Eggermont, H., Cocquyt, C., Francus, P., Cazet, J-P., Fagot, M., Rumes, B., Russell, J. M., Darius, F., Conley, D. J., Schuster, M., Suchodoletz, H. \& Engstrom, D. R. 2008: Climate-driven ecosystem succession in the Sahara: the past 6000 years. Science 320, 765-768.

Kuper, R. \& Kröpelein, S. 2006: Climate-controlled Holocene occupation in the Sahara: motor of African evolution. Science 313, 803-807.

Kusky, T. M., Ramadan, T. M., Massaan, M. M. \& Gabr, S. 2011: Structural and Tectonic Evolution of El - Faiyum Depression, North Western Desert, Egypt based on analysis of Landsat ETM+ and SRTM data. Journal of Earth Science 22, 75-100.

Löffler, H. W. 1986: Ostracod analysis. In Berglund, B. E. (ed.): Handbook of Holocene Palaeoecology and Palaeohydrology, 693-702. Wiley \& Sons, Chichester.

Ložek, V. 1986: Mollusca Analysis. In Berglund, B. E. (ed.): Handbook of Holocene Palaeoecology and Palaeohydrology, 729-740. Wiley \& Sons, Chichester. 
Marks, L., Salem, A., Welc, F., Nitychoruk, J., Chen, Z., Zalat, A., Majecka, A., Chodyka, M., Szymanek, M. \& Tołoczko-Pasek, A. 2016: Preliminary report on unique laminated Holocene sediments from the Qarun Lake in Egypt. Studia Quaternaria 33, 35-46.

Marshall, M, H., Lamb, H. F., Davies, S. J., Leng, M, J., Umer, M,. Bryant, Ch. \& Kubsa, Z. 2009: Climatic change in northern Ethiopia during the past 17,000 years: A diatom and stable isotope record from Lake Ashenge. Palaeogeography, Palaeoclimatology, Palaeoecology 279, 114-127.

McCorriston, J. 2006: Breaking the rain barrier and the tropical. spread of near eastern agriculture into southern Arabia. In Kennett, D. J. \& Winterhalder, B. (eds.): Behavioral Ecology and the Transition to Agriculture, 217-236. University of California Press, Berkeley.

Neale, J. V. 1988: Ostracods and palaeosalinity reconstruction. In De Deckker, P., Colin, J. P. \& Peypouquet, J. P. (eds.): Ostracoda in the Earth Sciences, 125-155. Elsevier, Amsterdam.

Nicoll, K. 2004: Recent environmental change and prehistoric human activity in Egypt and northern Sudan. Quaternary Science Reviews 23, 561-580.

Overpeck, J., Anderson, D., Trumbore, S. \& Prell, W. 1996: The southwest Indian Monsoon over the last 18,000 yrs. Climate Dynamics 12, 213-225.

Pachur, H. J., Kröpelin, S., Hoelzmann, P., Goschin, M. \& Altmann, N. 1990. Late Quaternary fluvio-lacustrine environments of western Nubia. Research in Egypt and Sudan 120, 203-260.

Park, L. E. \& Martens, K. 2001: Four new species of Gomphocythere (Crustacea, Ostracoda) from Lake Tanganyika, East Africa. Hydrobiologia 450, 129-147. 
Przybyłowska-Lange, W. 1976: Diatoms from the site E71K14, area 1, trench 1, upper diatomaceous silt. In Wendorf, F. \& Schild, R. (eds.): Prehistory of the Nile Valley, 321 323. Academic Press, New York.

Reimer, P. J., Bard, E., Bayliss, A., Beck, J. W., Blackwell, P. G., Bronk Ramsey, C., Buck, C. E., Cheng, H., Edwards, R. L., Friedrich, M., Grootes, P. M., Guilderson, T. P., Haflidason, H., Hajdas, I., Hatté, C., Heaton, T. J., Hoffmann, D. L., Hogg, A. G., Hughen, K. A., Kaiser, K. F., Kromer, B., Manning, S. W., Niu, M., Reimer, R. W., Richards, D. A., Scott, E. M., Southon, J. R., Staff, R. A., Turney, C. S. M. \& van der Plicht, J. 2013: IntCal13 and Marine13 radiocarbon age calibration curves 0-50,000 years cal. BP. Radiocarbon 55,1869-1887.

Revel, M., Colin, C., Bernasconi, S., Combourieu-Nebout, N. C., Ducassou, E., Grousset, F. F., Rolland, Y., Migeon, S., Bosch, D., Brunet, P., Zhao, Y. \& Mascle, J. 2014: 21,000 Years of Ethiopian African monsoon variability recorded in sediments of the western Nile deep-sea fan. Regional Environmental Change 14, 1685-169.

Richardson, J. L., Harvey, T. J. \& Holdship, S. A., 1978: Diatoms in the history of shallow East African lakes. Polskie Archiwum Hydrobiologii 25, 341-343.

Rohling, E. \& Pälike, H. 2005: Centennial-scale climate cooling with a sudden cold event around 8,200 years ago. Nature 434, 975-979.

Said, R. 1979: The Messinian in Egypt. Proceedings of the International Congress on Mediterranean Neogene, Athens. Annales Geologiques des Pays Helleniques III, 10831090.

Said, R. 1981: The Geologic Eevolution of the River Nile. 151 pp. Springer, New York.

Sattmann, H. \& Kinzelbah, R. 1988: Notes on inland water molluscs from Egypt (Mollusca: Gastropoda, Bivalvia). Zoology in the Middle East 2, 72-78. 
870 Schild, R., Wendorf, F. 2001. Geoarchaeology of the Holocene Climatic Optimum at Nabta 871 Playa, Southwestern Desert, Egypt. Geoarchaeology 16, 7-28.

872 Schild, R. \& Wendorf, F. 2013: Early and Middle Holocene palaeoclimates in the 873 Southwestern Desert of Egypt - the world before unification. Studia Quaternaria 30, 125 $874-133$.

875 Shen, Z. X., Arimoto, R., Okuda, T., Cao, J. J., Zhang, R. J., Li, X. X., Du, N., Nakao, S. \& Tanaka, S. 2008: Seasonal variations and evidence for the effectiveness of pollution controls on water-soluble inorganic species in total suspended particulates and fine particulate matter from Xi'an, China. Journal of Air Waste Management Association 58: $1560-1570$.

880

881

882

883

884

885

886

887

888

889

890

891

892

893

894

Stoermer, E. F., Bowman, M., Kingston, J. C. V. \& Schaedel, A. L. 1975: Phytoplankton composition and abundance in Lake Ontario during IFYGL. U.S. Environmental Protection Agency. Report No. EPA-660/3-75-004. February 1975, Corvallis, Oregon.

Stuiver, M. \& Polach, H. A. 1977: Discussion reporting of C14 data. Radiocarbon 19, 355363.

Sywula, T. 1974: Małżoraczki (Ostracoda). Fauna stodkowodna Polski 24. 315 pp. Państwowe Wydawnictwo Naukowe, Poznań.

Taraschewski, H. \& Paperna, I. 1981: Distribution of the snail Pirenellaconica in Sinai and Israel and its infection by Heterophydae and other Trematodes. Marine Ecology Progress Series 5, 193-205.

Tibby, J. \& Reid, M. 2004: A model for inferring past conductivity in low salinity waters derived from Murray River diatom plankton. Marine and Freshwater Research 55, 587607.

Trigueros, M. \& Orive, E. 2000: Tidally driven distribution of phytoplankton blooms in a shallow, macrotidal estuary. Journal of Plankton Research 22, 969-986. 
895 Welc, F. \& Marks, L. 2014: Climate change at the end of the Old Kingdom in Egypt around 8964200 BP: New geoarcheological evidence. Quaternary International 324, 124-133.

897 Weldeab, S., Lea, D. W., Schneider, R. E. \& Andersen, N. 2007: 155,000 years of West 898 African monsoon and ocean thermal evolution. Science 316, 1303-1307.

899 Welter-Schultes, F. 2012: European Non-Marine Molluscs, a Guide for Species $900 \quad$ Identification. 76 pp. Planet Poster Editions, Goettingen.

901 Wendorf, F. \& Schild, R. 1976: The Prehistory of the Nile Valley. 404 pp. Academic Press, $902 \quad$ New York.

903

904

905

906

907

908

909

910

911

912

913

914

915

916

917

918

Wenke, R. J., Long, J. E. \& Buck, P. E. 1988: Epipalaeolithic and Neolithic subsistence and settlement in the Faiyum Oasis in Egypt. Journal of Field Archaeology 15, 29-51.

Williams, M. A. J., Adamson, D., Cock, B. \& McEvedy, R. 2000: Late Quaternary environments in the White Nile region, Sudan. Global and Planetary Change 26, 305-316.

Wolfe, A. P., Fréchette, B., Richard, P. J. H., Miller, G. H. \& Forman, S. L. 2000: Palaeoecological assessment of a 90,000-year lacustrine sequence from Fog Lake, Baffin Island, Arctic Canada. Quaternary Science Reviews 19, 1677-1699.

Woodward, J. C., Macklin, M. G., Krom, M. D. \& Williams, M. A. J. 2007: The Nile: evolution, Quaternary river environments and material fluxes. In Gupta, A. (ed.): Large Rivers: Geomorphology and Management, 262 - 292. Wiley \& Sons, London.

Zalat, A. A. 1991: Paleontological. studies on the Quaternary diatomite of the Fayoum Depression, Western Desert, Egypt. Ph.D. thesis, Tanta University, 329 pp.

Zalat, A. A. 1995: Calcareous nannoplankton and diatoms from the Eocene/Pliocene sediments, Fayoum depression, Egypt. Journal of African Earth Sciences 20, 227-244.

Zalat, A. A. 2002: Distribution and origin of diatoms in the bottom sediments of the Suez canal lakes and adjacent areas, Egypt. Diatom Research 17, 243-266. 
919 Zalat, A. A. 2015: Holocene diatom assemblages and their palaeoenvironmental 920 interpretations in Fayoum Depression, Western Desert, Egypt. Quaternary International $921369,86-98$.

922 Zalat, A. A. \& Servant-Vildary S. 2005: Distribution of diatom assemblages and their 923 relationship to environmental variables in the surface sediments of three northern Egyptian 924 lakes. Journal of Palaeolimnology 34, 159-174.

925 Zalat, A. A. \& Servant-Vildary S. 2007: Environmental change in northern Egyptian Delta 926 lakes during the late Holocene, based on diatom analysis. Journal of Paleolimnology 37, $927 \quad 273-299$. 


\section{Captions to the figures and tables}

929 Fig. 1. Location sketch; A - after Woodward et al. (2007), modified; B - based on broad

930 compilation, bathymetry of the lake is after Abu-Zied et al. (2007).

931 Fig. 2. Lithology of core FA-1.

932 Fig. 3. Age-depth model of the core FA-1. Top panels reflect: the MCMC process (left), the 933 prior and posterior distributions for the deposition time (middle) and its variability between depths (right). The main panel shows the calibrated radiocarbon dates and the age-depth model (grey-scale, with darker areas indicating more secure sections). Stippled curves indicate $95 \%$ range and curve between them indicates a mean. Depths are in $\mathrm{cm}$.

937 Fig. 4. Sedimentation rate and model of deposition in the lake.

938 Fig. 5. Variation of water soluble ions in sediments of core FA-1.

Fig. 6. Percentage diagram of selected diatoms in the FA-1; sediment without diatoms is indicated in gray.

941

Fig. 7. Main phases of the Qarun Lake development indicated in core FA-1; for lithological description see Fig. 2.

Fig. 8. Palaeogeography of the Faiyum Oasis in the Holocene with past lake extents (in dark gray); indicated are the present lakes (in black), the area above $50 \mathrm{~m}$ a.s.l. (in light gray) and contour lines at $0 \mathrm{~m}$ and $-25 \mathrm{~m}$ b.s.1.

Table 1. List of radiocarbon dates in core FA-1; concentrations of organic matter are indicated but dispersed organic matter occurred in every sample. Calibrated ranges are based on Oxcal 2016 with $95.4 \%$ probability; AMS $\delta^{13} \mathrm{C}$ values are for correcting measurementinduced fractionation and should not be interpreted ecologically.

Table 2. Molluscs and ostracods of core FA-1. 
$952 \quad \mathrm{~F}-$ freshwater: $s-$ stagnant water, $f-$ flowing water; Sa - saltwater: $b r-$ brackish; $d-$ 953 shell detritus, $f r$ - few fragments of shell, 2-6 - phases of the lake based on sedimentary 954 sequence; for bivalves and ostracods a number of valves is given 

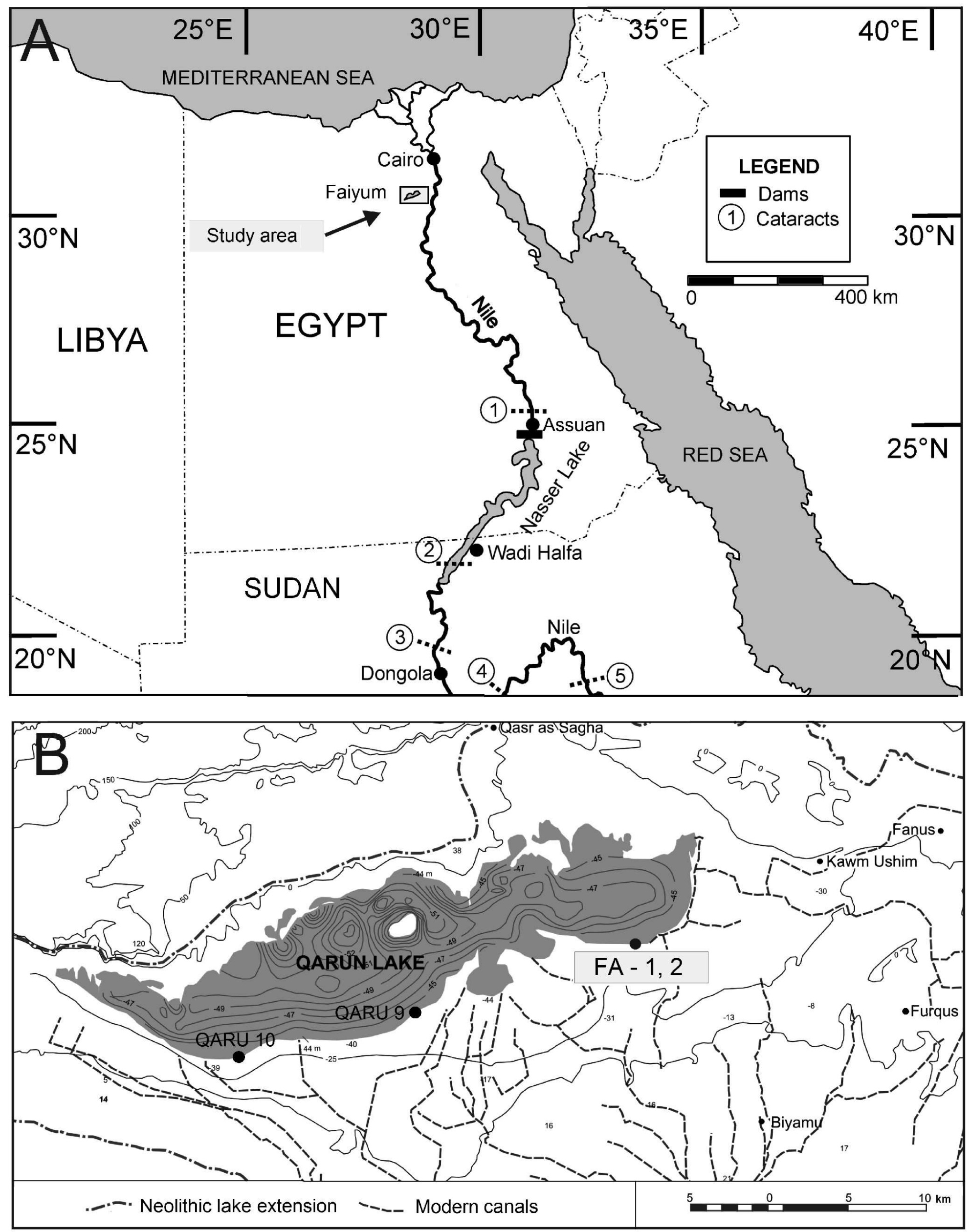


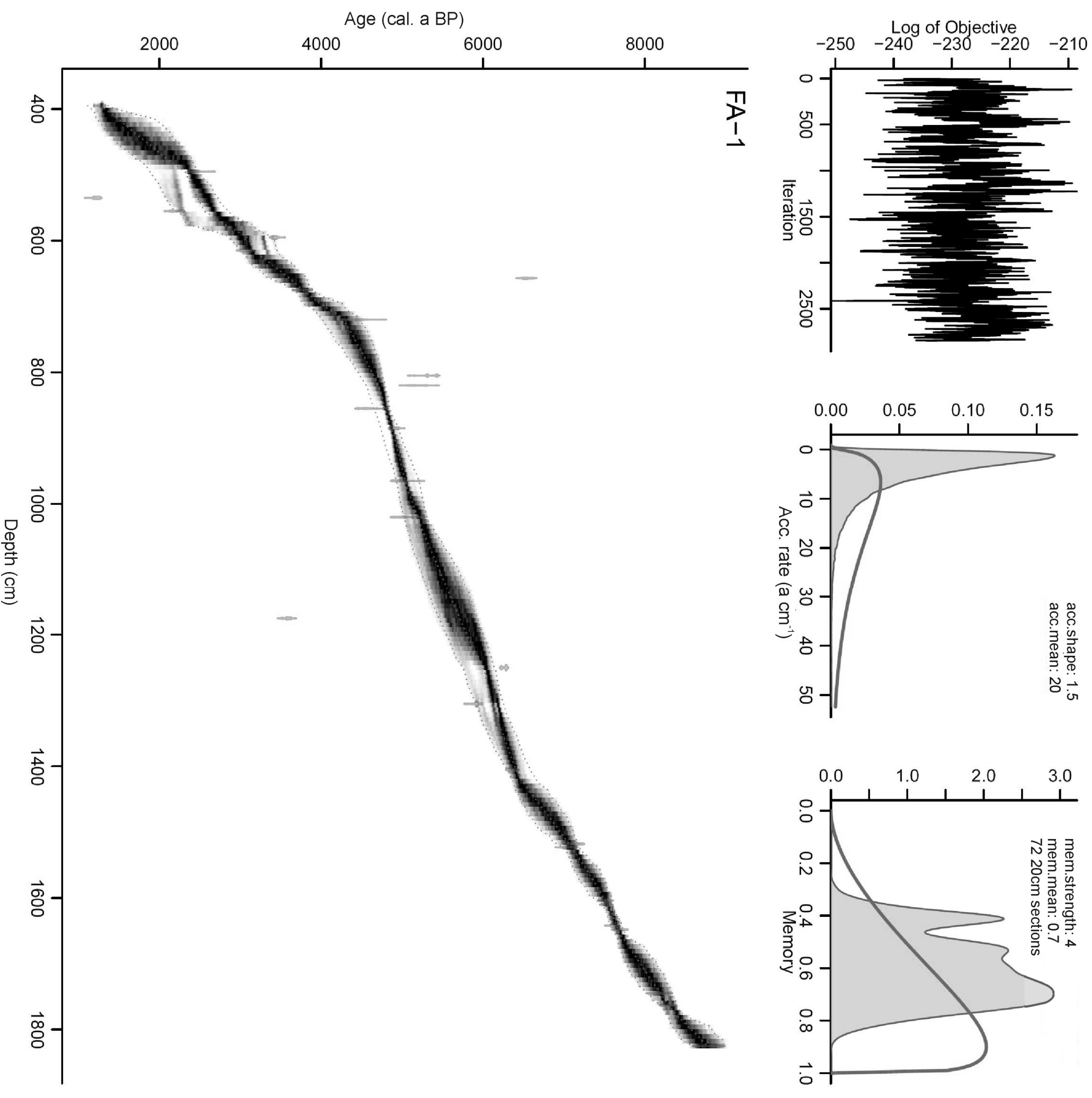




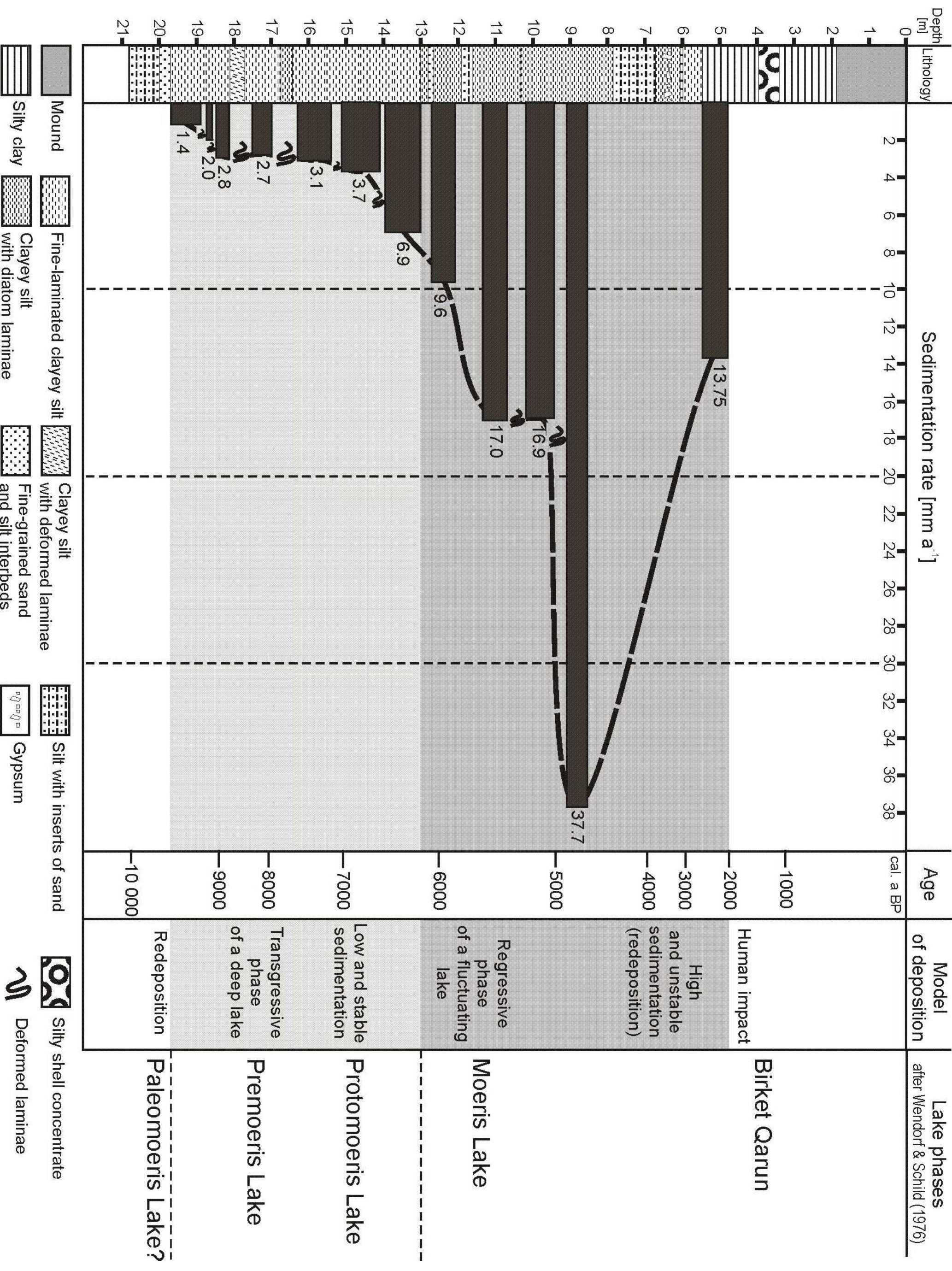




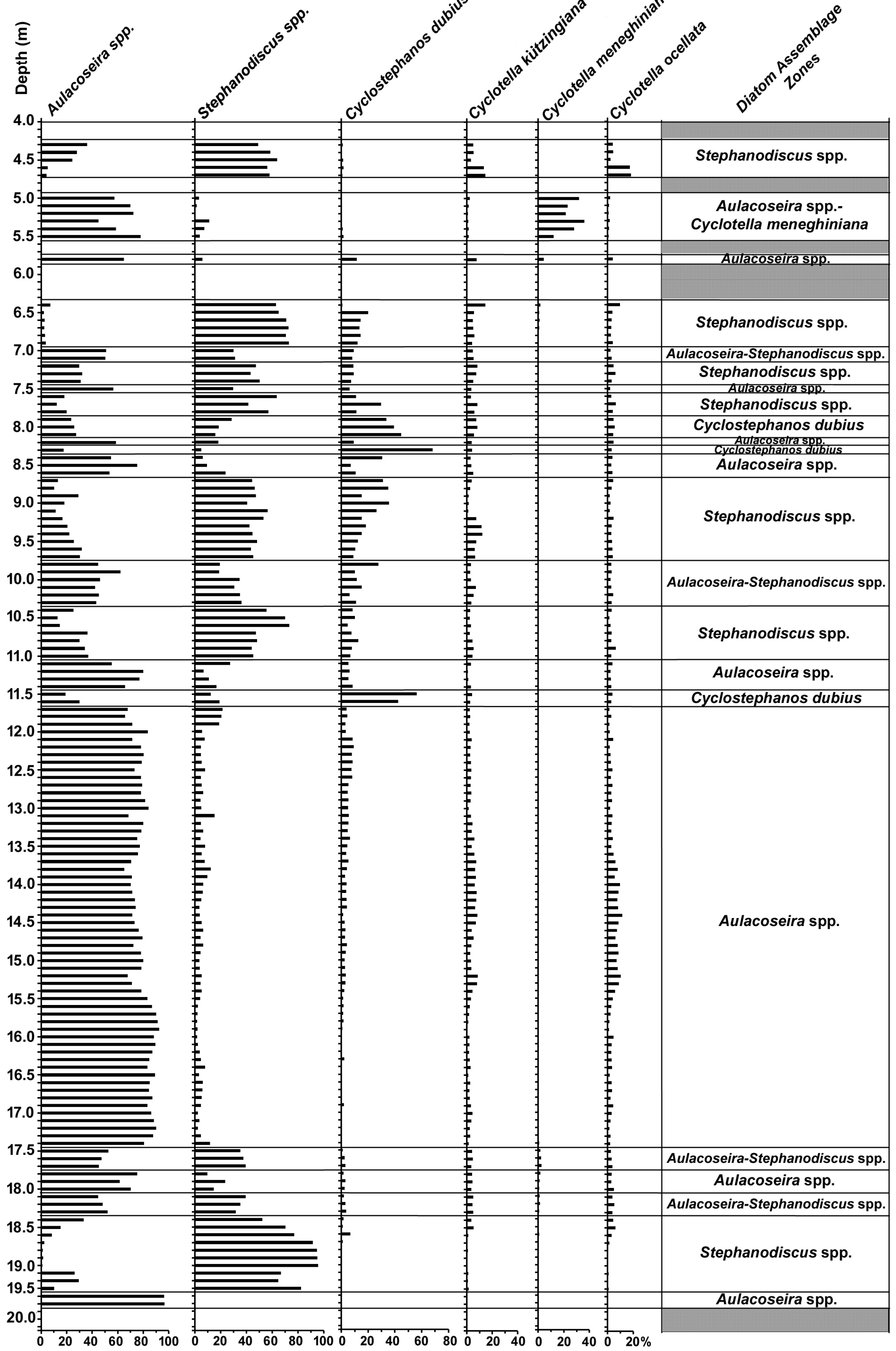




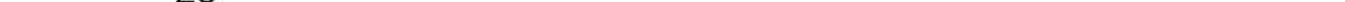


